УДК 630*22(477.44)

DOI: 10.37128/2707-5826-2020-3-13

\title{
SPECIFIC FEATURES OF FORMATION OF VINNYTSIA FOREST PARK PLANTATIONS RESISTANT TO RECREATIONAL LOADS
}

M. V. MATUSIAK, Candidate of

Agricultural Sciences, Associate

Professor, Vinnytsia National

AgrarianUniversity

The research conducted was to assess the characteristics of intraspecific and interspecific interaction of the dominant tree species in the forest-park plantations of Vinnytsia green zone, as well as to determine the priority taxation indicators of formation of forest stands with high competitive ability. As a result of the research it was found that the main indicators that directly affect the competitive properties of forest elements are the sanitary condition of forest plantations; the composition of the stand and its storey structure; the undergrowth and underwood availability; biological and ecological features of individual tree species; stand completeness; age of planting; type of forest vegetation conditions; specific features of microclimate and microrelief. The analysis of the sanitary condition of the trial areas shows that the degree of competitive ability of forest plantations with a high number of dead or damaged trees is much lower than that in plantations with better sanitary conditions.

The dependence of the competitive ability and the stand growth intensity on its completeness and the type of forest-park landscape was also studied. Thus, closed types of stands are characterized by a high degree of competitiveness. In semi-open types of forest-park landscapes the rate of growth intensity is the highest. The competitive ability of trees in this type of landscape is quite low.

After analyzing the temperature regime of different forest parks, it was found that in hot weather the ambient temperature in the forest park is much lower than the air temperature in the open area. Thus, in hot uncomfortable weather, the optimal type of forest for recreation is a closed type of landscape of vertical closure. The air temperature here can be significantly lower (up to $15^{\circ} \mathrm{C}$ ) compared to the open space, what creates suitable conditions for a comfortable rest.

Analysis of the humidity of forest parks showed that under the cover of forest stands humidity is higher than in the open area, thus recommendations for choosing the type of forest landscape for recreation purposes depend on the initial humidity.

Key words: recreation, forest parks, intraspecific interaction, forest park landscape, winter hardiness, temperature regime, light intensity, air humidity.

Tabl. 2. Fig. 2. Lit. 9.

Problem setting. The main issue today is to realize the problems of the environment and to determine the best ways to solve them. Suburban forests can become a central link in solving ecological problems of the cities. Among all others 
natural complexes they are the main factor in protection and stabilization of the urban environment. Society's need for recreational, sanitary, protective and other functions of forest is growing compared to the stable needs for other forest resources, in particular, wood. In previous years forests were seen only as a source of material goods, but today they are also considered as an important socio-cultural value $-\mathrm{a}$ guarantee of sustainable development of mankind due to their global environmental functions [3].

Recreational forests, in particular suburban ones, acquire special significance in meeting the ecological and social needs of the society. Therefore, there is a need to determine the role and place of suburban forests in the world, and Ukraine in particular, in order to establish the main priorities for forestry practices in them. Awareness of the key biosphere role of the suburban forests, formed in the context of international processes and initiatives at the end of the 20th century, led to formation of a new paradigm of forest management on the basis of sustainable development which will allow improving their viability. One of the main issues of preserving the ecological balance of suburban forests is the study and maintenance of their species diversity. Maintaining, conserving and improving biodiversity in forest ecosystems is an integral indicator of forest management efficiency and a key condition for the sustainable forest management.

It should be mentioned, that study of the species diversity in recreational forests has always occupied an important place in botanical research both in the world and in Ukraine. Many years of research on the dynamics of biodiversity, conducted in the suburban forests of many countries, show negative trends, including the reduction and anthropogenic changes in the species composition of phytodiversity and extinction of the rare species. It was also noticed, that the species diversity in urban and suburban forests in terms of quantity and quality differs significantly from the less accessible for recreation forests. Composition and condition of species diversity are important indicators for determining the degree of digression of forest cenoses [5].

Analysis of the recent publications. Analysis of the world's scientific literature proves the importance of suburban forests which are gaining new meaning in the world. In this regard, there is a need to rethink the strategy of forestry practices in suburban forests in accordance with modern requirements. The urgency of the issue is also conditioned by the uncertainty of strategic goals, principles and systems of forestry in the suburban forests of Ukraine. According to Yu.M. Pozyvailo, each vacationist visits suburban forests averagely 8-10 times a year and spends 3-4 hours in them, what leads to a significant violation of the forest biocenosis [7]. In their works V.N. Diadko, T.A. Polyakova note, that due to significant recreational loads the soil structure is disturbed, its hardness, total density and air capacity increases, while humidity, humus content and thickness of the humus layer decreases [5].

Materials and methods of the research. Peculiarities of different types of forest park landscapes formation were studied in the most representative areas of 
forests in the green zone of Vinnytsia, the characteristics of which were obtained by analyzing the forest fund of the forest-park zones. The most typical plots in forestpark zones were selected and the necessary temporary trial areas (TA) were laid at them. Trial areas were laid in the predominant types of forest vegetation conditions of the green zone of Vinnytsia - D2, B2, C2, i.e. the research was not conducted in wet hygrotopes, unsuitable or undesirable for recreational purposes. Generally 12 TA were selected, which included $8 \mathrm{TA}$ in closed types of forest park landscapes of horizontal closure, 4 TA in closed types of forest park landscapes of vertical closure.

The shape of the TA was taken as rectangular. In young stands TAs were: in the medium-aged ones -0.4 ha $(50 \times 80 \mathrm{~m})$, in the ripening -0.5 ha $(100 \times 50 \mathrm{~m})$.

Since the object of the study is a recreational area, the requirements for the landscape taxation were taken into account when laying the TAs. In the process of the field work at each TA, a checklist was filled in. The region, administrative district, forest park, forestry, tax quarter and allocation were specified. The main taxonomic indicators of the stand, obtained by instrumental taxonomic measurements according to generally accepted methods with the use of normative reference materials [8], were established.

For the analysis of the species diversity, an approach was used, which consisted in determining the indices of diversity, which constitute the relationship or other mathematical expressions of the relationship between the number of species and their significance. Species diversity was investigated by studying the spring aspect of the tree-shrub and grass-shrub storeys. Ukrainian and Latin names of plants were used in accordance to the index of higher plants of Ukraine. Ecological analysis of plant lists of each typological description was performed by the cameral method according to the compliance of plants with certain types of forest vegetation conditions [9].

\section{Results and discussion.}

Within the forest areas, there exists heterogeneity of horizontal and vertical structures, which is primarily due to the uneven distribution of trees in forest areas and the storey character of the forest stands.

Horizontal and vertical heterogeneity of the forest stand is caused both by soil and climatic conditions of the location of growth, and by bioecological features of the species, differences in the nature of their distribution, reproduction, growth, etc.

Horizontal and vertical structures of the stands have the following characteristics: mosaic character, abundance, occurrence, storey structure. These signs of heterogeneity of stands determine decorative properties of the forest-park landscapes and condition diversity, volume perception and contrast of the forest elements.

Mosaicity is understood as a general sign of vegetation heterogeneity and the presence of horizontal division of vegetation within one group.

The mosaic character of vegetation is closely related to the occurrence of plants, which reflects the uniformity of their distribution and abundance. Stands of the closed type of forest-park landscape with vertical and horizontal closure have high 
abundance and occurrence of trees on the area. Semi-open types of the forest-park landscapes with uniform distribution of trees on the area are characterized by medium abundance and significant occurrence, and with the uneven one - low abundance and low occurrence.

Mosaicity, abundance and occurrence can be determined by the peculiarities of location of trees in the stand, both without differentiation by species and separately by certain species. In mixed forests of all types of forest-park landscapes, these features have higher showings. In this case, the horizontal structure of mixed plantations has higher decorative properties than pure ones.

The sign of forest stands sorey structure is characteristic only for the closed type of forest-park landscapes of vertical closure. Vertical closure can have smooth or variegated transitions from one storey to another. From the aesthetic point of view, variegated vertical closure is considered to be more spectacular than the smooth one.

It should be noted, that one of the disadvantages of artificial afforestation is the uniform and linear arrangement of trees on the area, which is not typical of natural forests. Such arrangement of trees on the area reduces the aesthetic properties of forests. Reformation of forest plantations with a uniform row arrangement of trees on the area involves fellings, after which the left trees allow to avoid the visual appearance of linear plantings.

Having analyzed the horizontal and vertical structures of forest-park landscapes and the peculiarities of their formation, we can make the following generalizations:

1. Horizontal and vertical inhomogeneities of forest stands determine the type of the forest-park landscapes and their decorative features.

2. Horizontal structure of semi-open types of forest-park landscapes has medium and low indicators of these features. Semi-open landscapes with uneven arrangement of trees on the area have a contour mosaicity, and with a uniform arrangement - a smooth one.

3. Peculiarities of formation of horizontal and vertical structure of forest stands consist in fellings, or removal of those trees which emphasize linear character of plantings. It is necessary to leave those trees that help to avoid visual perception of trees arranged in lines in the forest stand [4].

Analysis of the interaction of tree species shows that the impact of one species on another hardly ever occurs directly, but mostly indirectly, sometimes through quite complex biological chains. Interaction of species for all their diversity may be reduced to two categories:

1. Interaction, which is manifested in competition for light, moisture, nutrients, etc.

2. Interaction that occurs as a result of the influence of one species on another through phytoncides and other secretions, including root ones.

Much attention to determining the interaction of tree and shrub species is quite justified as any forestry measure in pure or mixed stands must take into account interspecific and intraspecific interaction of the species that are the part of it. It is 
necessary to know the peculiarities of interaction of tree and shrub species of forestpark plantations in order to determine the rationality of composition in the medium, ripening and mature age, as well as to establish, for example, the feasibility of introducing associated species or undergrowth in forest plantations. Thus, the study of interaction of tree species involves identification of intraspecific and interspecific competition or mutual assistance in order to completely eliminate or reduce negative symptoms or maximize benefits of this interaction.

Our research also consisted in assessing specific features of intraspecific and interspecific interaction of the dominant tree species in the forest-park plantations of Vinnytsia green zone, as well as in determining the priority taxation indicators of formation of forest stands with high competitive capacity.

As a result of the research it was found that main indicators that directly affect the competitive properties of forest elements are: sanitary condition of the forest plantations; composition of the stand and its storey structure; undergrowth and underwood availability; biological and ecological features of individual tree species; stand completeness; age of planting; type of forest vegetation conditions; specific features of microclimate and microrelief.

From the analysis of the sanitary condition of forest TAs follows that the degree of competitiveness of forest plantations with a high number of dead or damaged trees is much lower than in plantations with better sanitary condition. This fact is stressed by D.D. Lavrinenko, who proposed to determine the competitiveness of forest plantations by the average Kraft class. Thus, at TA No. 5, 3, 6, 8 (see Table 1) using K.K. Vysotskyi's method, a high intensity of tree growth in the forest stand was recorded. Average Kraft class of trees in the forests of the mentioned TAs is from II, 5 and less. According to D.D. Lavrinenko's method plantations with such average Kraft's class are characterized by medium and weak degree of potential competitiveness [3]. Thus, the sanitary condition is an indicator of certain competitive properties of wood species that grow in the forest stand.

The species composition of stands determines the specific features of competitiveness of both individual species and the forest in the whole. It was determined that pioneer species and fast-growing species in most cases have a relatively high degree of competitive ability. The growth rate of these species is significantly lower than that of the others. We found that in conditions of Vinnytsia green zone Betula pendula Roth., Quercus robur L. and Quercus borealis Michx. are characterized by the best competitive properties and high decorative qualities. Other species, including introducers, should be given the role of accompanying trees.

Undergrowth and underwood have a special influence on the interaction of tree species. They can affect both positively and negatively on the stand as a whole or on individual species that are part of it. Thus, a pine stand with dense undergrowth located on TA No. 10 (see Table 1) has an increased growth rate. Obviously, it occures due to the competition between trees and shrubs for nutrients, water and light. 
A similar situation is observed in multistorey stands. The rate of growth of the second storey is much higher than that of the first one.

Dependence of the competitiveness and growth intensity of the stand on its completeness and on the type of forest-park landscape was also investigated. Thus, closed types of stands are characterized by a high degree of competitiveness. In semiopen types of forest-park landscapes, the rate of growth intensity was the highest. Competitive ability of trees in this type of landscape was quite low.

The established regularity of the peculiarities of the interaction of tree species with the age can be clearly traced on the example of TA No. 9 (see Table 1), laid in different age tree stands. As part of this plantation, along with thirty-year-old species of Quercus borealis Michx. and Acer platanoides L. grow single century-old trees of

\section{Indicators of interaction of tree species}

Table 1

\begin{tabular}{|c|c|c|c|c|c|c|c|c|}
\hline No. & $\begin{array}{c}\text { Composition } \\
\text { of the stand }\end{array}$ & $\begin{array}{l}\text { Age, } \\
\text { years }\end{array}$ & $\begin{array}{l}\text { Type } \\
\text { of } \\
\text { forest- } \\
\text { plant } \\
\text { conditi } \\
\text { ons }\end{array}$ & Fullness & Species & $\begin{array}{c}\text { Average } \\
\text { Kraft } \\
\text { class }\end{array}$ & $\begin{array}{l}\text { Growth rate } \\
\text { indicator }\end{array}$ & $\begin{array}{l}\text { Indicator of } \\
\text { the degree of } \\
\text { the stands } \\
\text { stability }\end{array}$ \\
\hline 1 & 2 & 3 & 4 & 5 & 6 & 7 & 8 & 9 \\
\hline 2 & 5Qr5Bp & 25 & $\mathrm{D}_{2}$ & 0,65 & $\begin{array}{l}\text { Qercus robur } \\
\text { Betula pendula }\end{array}$ & $\begin{array}{l}\text { II, } 1 \\
\text { II, } 2\end{array}$ & $\begin{array}{l}33,1 \\
31,6\end{array}$ & $\begin{array}{l}0,03 \\
0,03\end{array}$ \\
\hline 3 & $8 Q r 2 B p+P s$ & 25 & $\mathrm{D}_{2}$ & 0,60 & $\begin{array}{c}\text { Qercus robur } \\
\text { Betula pendula } \\
\text { Pinus silvestris }\end{array}$ & $\begin{array}{l}\text { II,5 } \\
\text { II,3 }\end{array}$ & $\begin{array}{c}13,3 \\
27\end{array}$ & $\begin{array}{l}0,04 \\
0,04\end{array}$ \\
\hline 4 & 6Qr2Bp2Pe & 25 & $\mathrm{D}_{2}$ & 0,55 & $\begin{array}{l}\text { Qercus robur } \\
\text { Betula pendula } \\
\text { Picea excelsa }\end{array}$ & $\begin{array}{l}\text { II, } 8 \\
\text { III,3 } \\
\text { III, } 1\end{array}$ & $\begin{array}{c}11,9 \\
32 \\
35\end{array}$ & $\begin{array}{l}0,04 \\
0,03 \\
0,03\end{array}$ \\
\hline 5 & 6Qr4Bp & 30 & $\mathrm{D}_{2}$ & 0,70 & $\begin{array}{c}\text { Qercus robur } \\
\text { Betula pendula }\end{array}$ & $\begin{array}{l}\text { II, } 2 \\
\text { II, } 2\end{array}$ & $\begin{array}{l}22,6 \\
27,1\end{array}$ & $\begin{array}{l}0,04 \\
0,04\end{array}$ \\
\hline 6 & $6 \mathrm{C}_{3} 4 \mathrm{Qr}$ & 30 & $\mathrm{D}_{2}$ & 0,75 & $\begin{array}{l}\text { Pinus silvestris } \\
\text { Qercus robur }\end{array}$ & $\begin{array}{l}\text { II, } 2 \\
\text { II,6 }\end{array}$ & $\begin{array}{l}24,1 \\
30,4\end{array}$ & $\begin{array}{l}0,04 \\
0,03\end{array}$ \\
\hline 7 & 6Qr4Bp & 30 & $\mathrm{D}_{2}$ & 0,55 & $\begin{array}{l}\text { Qercus robur } \\
\text { Betula pendula }\end{array}$ & $\begin{array}{l}\mathrm{II}, 4 \\
\mathrm{II}, 5\end{array}$ & $\begin{array}{l}20 \\
25\end{array}$ & $\begin{array}{l}0,05 \\
0,04\end{array}$ \\
\hline 8 & 7QrBp + Ps & 32 & $\mathrm{D}_{2}$ & 0,65 & \begin{tabular}{|c|} 
Qercus robur \\
Betula pendula \\
Pinus silvestris \\
\end{tabular} & $\begin{array}{l}\text { II,6 } \\
\text { II,3 }\end{array}$ & $\begin{array}{l}28 \\
33 \\
\end{array}$ & $\begin{array}{l}0,04 \\
0,03 \\
\end{array}$ \\
\hline 9 & $\begin{array}{c}\text { 8Qrbr2Ap + } \\
\text { Qr }\end{array}$ & 30 & $\mathrm{D}_{3}$ & 0,80 & $\begin{array}{l}\text { Qercus rubra } \\
\text { Acer } \\
\text { platanoides } \\
\text { Qercus robur }\end{array}$ & $\begin{array}{l}\mathrm{I}, 4 \\
\mathrm{I}, 7\end{array}$ & $\begin{array}{l}12,5 \\
13,4\end{array}$ & $\begin{array}{l}0,08 \\
0,08\end{array}$ \\
\hline 10 & 7Qr2Bp1Fe & 31 & $\mathrm{D}_{2}$ & 0,55 & $\begin{array}{c}\text { Qercus robur } \\
\text { Betula pendula } \\
\text { Flaxinus } \\
\text { excelsior } \\
\end{array}$ & $\begin{array}{l}\text { III,3 } \\
\text { I,9 }\end{array}$ & $\begin{array}{c}10,2 \\
6,2\end{array}$ & $\begin{array}{c}0,1 \\
0,16\end{array}$ \\
\hline 11 & 7Qr3Bp & 50 & $\mathrm{D}_{2}$ & 0,65 & $\begin{array}{c}\text { Qercus robur } \\
\text { Betula pendula }\end{array}$ & $\begin{array}{l}\mathrm{I}, 4 \\
\mathrm{I}, 2\end{array}$ & $\begin{array}{l}6,1 \\
7,1\end{array}$ & $\begin{array}{l}0,16 \\
0,14\end{array}$ \\
\hline 12 & 5Ps5Bp & 56 & $\mathrm{~B}_{2}$ & 0,46 & $\begin{array}{l}\text { Pinus silvestris } \\
\text { Betula pendula }\end{array}$ & $\begin{array}{l}\mathrm{I}, 7 \\
\mathrm{I}, 6\end{array}$ & $\begin{array}{l}5,0 \\
6,4\end{array}$ & $\begin{array}{c}0,2 \\
0,16\end{array}$ \\
\hline
\end{tabular}

Source: based on own research 
the species Quercus robur L., Quercus borealis Michx. and Acer platanoides L., which are characterized by almost the same growth rate (12.5 and 13.4, respectively). The growth intensity of Quercus robur L. trees is significantly lower (2.1). The competitive capacity of the century-old Quercus robur L. is higher than that of the thirty-year-old Quercus borealis Michx and Acer platanoides L. trees. Thus, young trees have high growth intensity and low competitive ability. The intensity of tree growth in the stands weakens with the age, and competitiveness, on the contrary, increases.

Competitive relationships of tree species depend on the type of forest-plant conditions and increase with the enrichment of soil conditions.

The analysis of growth intensity indicators proves that even insignificant changes in growth conditions (both soil and climatic) have a noticeable influence on the competitiveness of tree species. Peculiarities of growth of the forest stand at TA No.3, located on a small hill, differs significantly from the similar forest stand of TA No.4, which is situated on the micro-lowering of the relief. The growth intensity of the first is higher (13.3) than that of the second (11.9).

This can be explained by the fact that changes in microrelief lead to microclimate changes. Forest plantations that grow in different microclimatic conditions are exposed to environmental factors that have significant differences. It comes about different light intensity, thermal and wind conditions. Forests that grow in the lower part of the terrain will have more favorable microclimate conditions and lower growth intensity compared to other plantations.

In addition, in conditions of high and low microrelief, plants obtain different supply of nutrients and moisture, the latter having great importance in the formation of forests of certain competitive ability. Thus, compared to the forest stand of TA No.3, forest plantation of TA No.4, which grows in the lower part of the relief, is better provided with moisture due to the close occurrence of groundwaters. TA No.3 was laid on a hill, where groundwater lies much deeper. This explains a relatively high rate of growth intensity and intraspecific competition in the forest stand [12].

After the analysis of interspecific relationships in young and medium-aged stands of the green zone of Vinnytsia, the following regularities have been established:

1. In addition to the main forest-forming species such as Betula pendula Roth., Quercus robur L., in the forest-park zone of the city in conditions of fresh and moist oaks groves and sub-oakeries we consider expedient more wide use of Quercus borealis Michx. Forest stands of this species have relatively high competitive and decorative properties. Trees of the species Quercus borealis Michx. in forest-park landscapes can play the role of background, accents and associated ones.

2. Competitive ability of tree species in the stand increases with its growth and enrichment of soil conditions. 
3. High rate of growth intensity is characteristic of forest stands with unsatisfactory sanitary condition, as well as of those that grow in the elevated part of the area.

The next aspect of our research was studying the influence of different stands of suburban forests on the formation of microclimate and creation of comfortable microclimatic conditions for recreation.

Climatic comfort of recreation consists in the positive influence of certain climatic factors on the peculiar heat sensation and heat exchange of the human body. Optimal combinations of wind speed, temperature and relative humidity form thermal comfort. The latter is established in the presence of the following conditions [26]: fluctuations in air temperature in the range of $16-22{ }^{\circ} \mathrm{C}$, relative humidity $-40-50 \%$, while the wind speed should not exceed $4 \mathrm{~m}_{\text {per s}}{ }^{-1}$.

The tasks of the research included also selection of the optimal types of forestpark landscapes according to the specific weather of the moment (in the conditions of different combinations of climatic factors), which will help to create the most possible comfortable conditions for recreation.

The intensity of sunlight in the forest area affects thermal sensation of the human body. In clear sunny summer weather, the light intensity reaches its maximal values, what leads to uncomfortable heat sensations. In this case, all types of closed types of forest-park landscapes should be considered optimal for recreation.

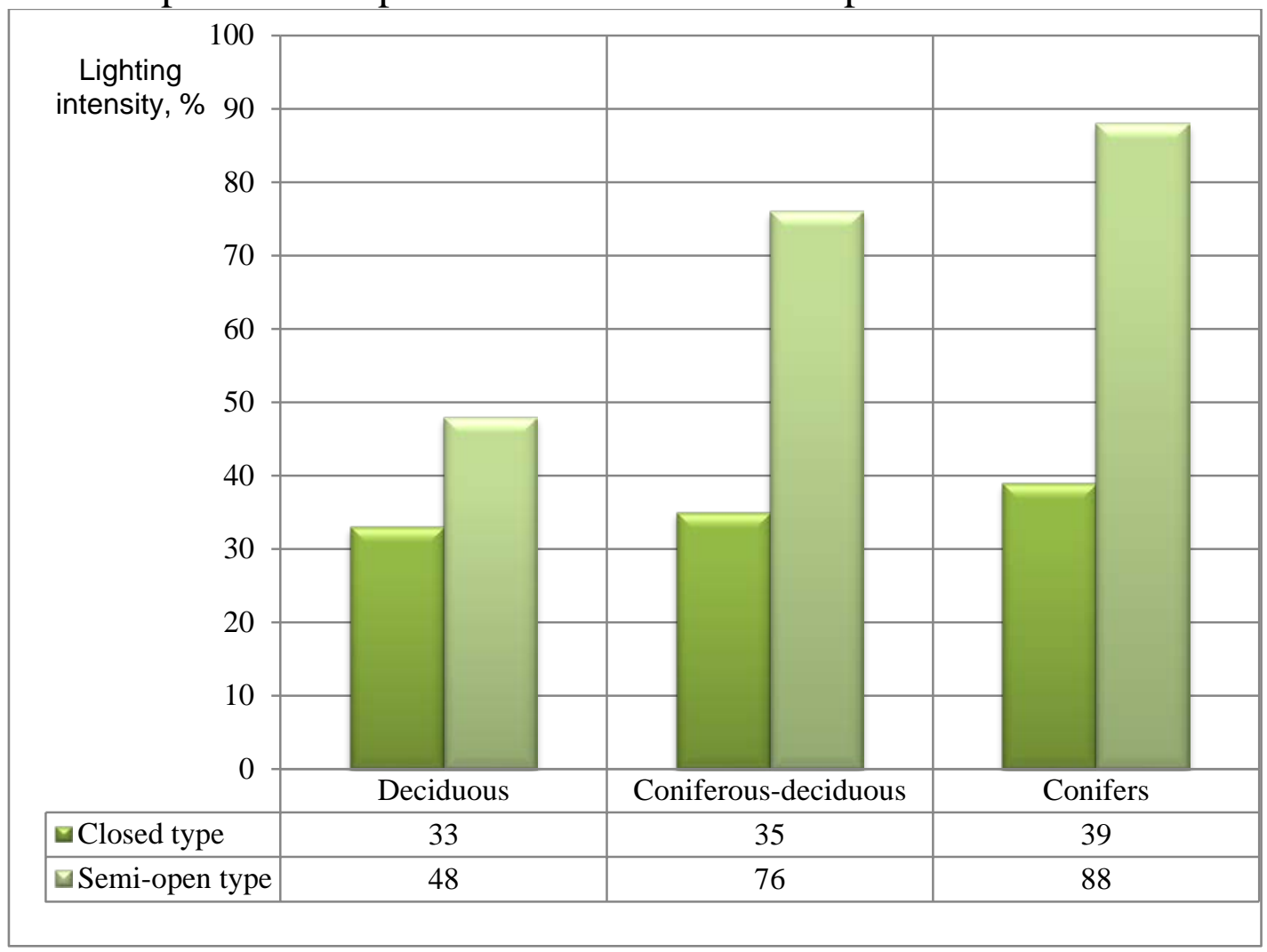

Fig.1. Intensity of the forest stands lighting at a height of $1.3 \mathrm{~m}$ in the young growth of forest-park landscapes

Source: based on own research 
Intensity of lighting under the forest cover also affects the heat exchange of the vacationers. In everyday life, in addition to the direct effects of solar radiation, a person is exposed to infrared radiation, which is reflected from the heated surfaces of the earth, vegetation, buildings, etc. Temperature of the surrounding surfaces largely determines thermal sensation of a person and thermal balance of the body [8].

Attractive for the vacationers may be the fact, that in the forest the temperature regime is more uniform and less different from the limit values: during the day it is cooler under the forest cover than in the open space, and at night, on the contrary, warmer. Thus, in hot weather, the ambient temperature of forest plantations is much lower than the air temperature in the open space, especially in the city. Therefore, in hot uncomfortable weather, the optimal type of forest for recreation is a closed type of landscape of vertical closure. The air temperature here can be significantly lower (up to $15^{\circ} \mathrm{C}$ ) compared to the open space, what creates conditions for a comfortable rest. In conditions of cold uncomfortable weather, forest plantations form a warmer temperature compared to the open space, thus creating favorable conditions for forest recreation. Thus, closed types of forest-park landscapes appeared to be optimal for the cold weather as well.

Humidity also affects the comfort of recreation conditions and in combination with other climatic factors determines specific features of microclimate in the forest. Given that under the cover of forest stands humidity is higher than in the open, recommendations for choosing the type of forest landscape for recreation depend on the initial humidity. In dry weather with low humidity, the most suitable for recreation are closed types of forest-park landscapes (Fig. 2).

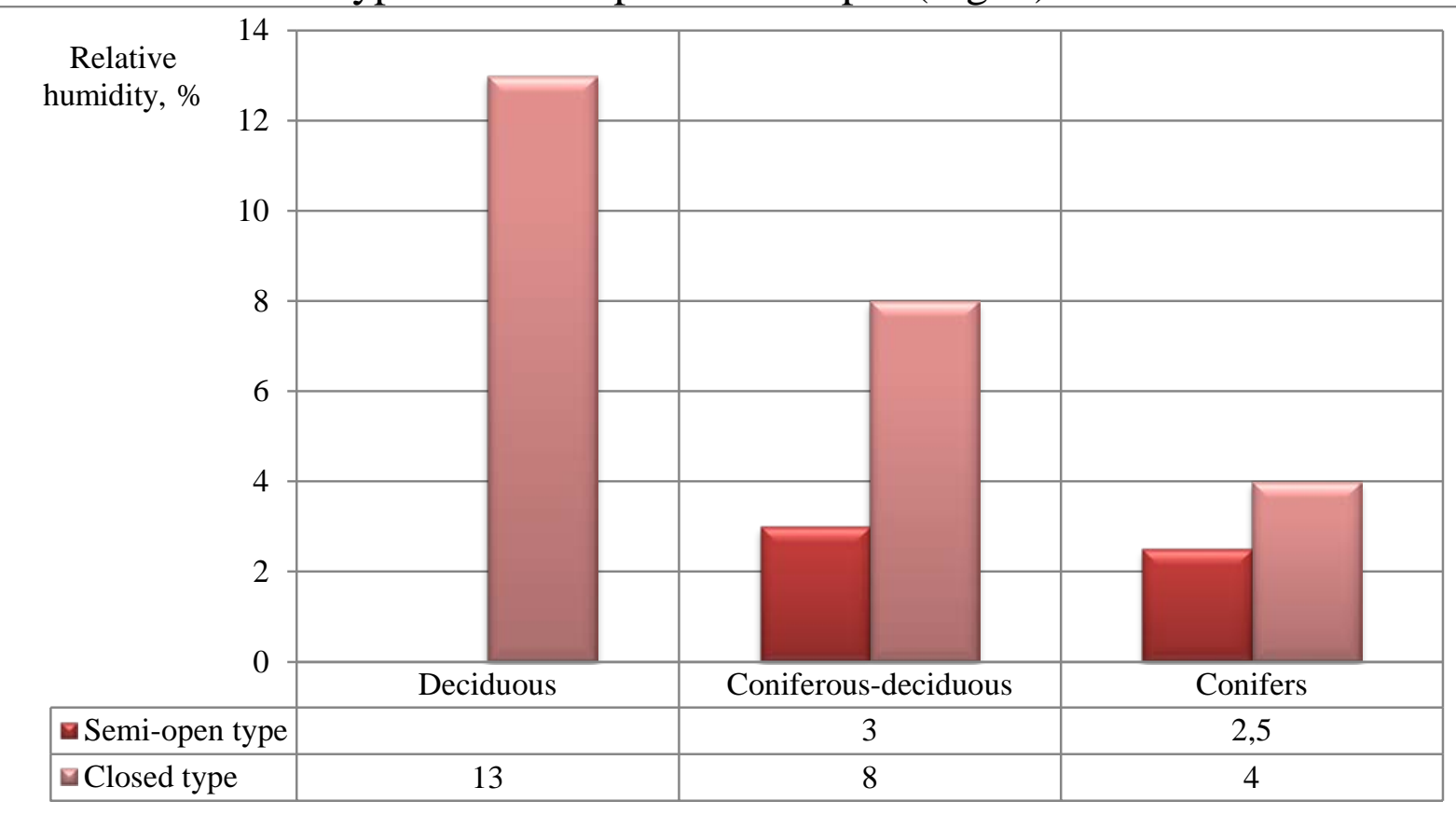

Fig. 2. Difference between the values of relative humidity in the forest-park

Source: based on own research

\section{medium-aged stands}


In such conditions humidity can increase by 5-15\% depending on the predominant tree species.

Semi-open types of forest-park landscapes are optimal in conditions of high humidity, as they do not significantly affect its value.

Wind speed in different weather conditions can make both positive and negative effects on the microclimatic conditions of forest-park landscapes. Weakening of wind force under the cover of forest and in the surrounding area is of great hygienic importance for the formation of the most favorable microclimate. Thus, during the research in high-density forest stands, the wind speed usually did not exceed $1 \mathrm{~m}$ per $\mathrm{s}^{-1}$. In windy comfortable and cool subcomfortable weather, the most suitable for recreation are closed types of forest-park landscapes of vertical closure, in particular deciduous and coniferous-deciduous forests stands, capable of holding up to $75 \%$ of wind speed.

In conditions of hot uncomfortable or warm subcomfortable weather, the wind speed of medium intensity and above average (1-3.5 $\mathrm{m}$ per s$\left.{ }^{-1}\right)$ has a positive effect on the thermal sensation of the human body. Under such weather conditions, semiopen types of forest landscapes proved to be optimal, under the cover of which active insolation of the air stay the same (see Table 2).

Table 2

\section{Spesific features of microclimate in young and medium-aged forests of different} forest-park landscapes types

\begin{tabular}{|c|c|c|c|c|c|c|c|c|}
\hline \multirow{4}{*}{$\begin{array}{l}\text { Forest } \\
\text { stands }\end{array}$} & \multicolumn{8}{|c|}{ Type of the forest-park landscape } \\
\hline & \multicolumn{4}{|c|}{ Closed } & \multicolumn{4}{|c|}{ Semi-open } \\
\hline & \multicolumn{8}{|c|}{ Microclimate indicies* } \\
\hline & $\begin{array}{c}\mathrm{T} . \\
\mathrm{d} .,{ }^{\circ} \mathrm{C}\end{array}$ & $\begin{array}{c}\text { H. d., } \\
\%\end{array}$ & $\begin{array}{l}\text { F. S. W. } \\
\text { r. c., \% }\end{array}$ & $\begin{array}{c}\text { F. e. w. } \\
\text { r. c., \% }\end{array}$ & $\begin{array}{c}\text { T. d., } \\
{ }^{\circ} \mathrm{C}\end{array}$ & $\begin{array}{c}\text { H. d., } \\
\%\end{array}$ & $\begin{array}{c}\text { F. e. W. } \\
\text { r. c., \% }\end{array}$ & $\begin{array}{l}\text { F. e. } \\
\text { w. r. } \\
\text { c., \% }\end{array}$ \\
\hline \multicolumn{9}{|c|}{ Young forest stands } \\
\hline Desiduous & $+4,2$ & -14 & 24 & 44 & $+3,4$ & -7 & 60 & 74 \\
\hline $\begin{array}{l}\text { Coniferous } \\
\text {-desiduous } \\
\end{array}$ & $+2,3$ & -7 & 25 & 48 & $+0,7$ & $-1,5$ & 68 & 86 \\
\hline Conifers & $+1,3$ & -6 & 31 & 53 & $+0,3$ & $-1,2$ & 73 & 92 \\
\hline \multicolumn{9}{|c|}{ Medium age forest stands } \\
\hline Desiduous & $+4,3$ & -11 & 28 & 41 & - & - & - & - \\
\hline $\begin{array}{l}\text { Coniferous } \\
\text {-desiduous } \\
\end{array}$ & $+3,5$ & -9 & 23 & 46 & $+1,2$ & -3 & 64 & 73 \\
\hline Conifers & $+2,7$ & -5 & 28 & 52 & $+1,3$ & $-2,8$ & 65 & 82 \\
\hline
\end{tabular}

* Note:

1. T. d. - difference between the average values of air temperature in the open area and in the forest;

2. H. d. - difference between the average values of relative humidity in the open area and in the forest;

3. F. s. w. r. c. - forest stand wind retention coefficient;

4. F. e. w. r. c. - forest edges wind retention coefficient.

Source: based on own research 
According to the analysis of Table 2, the most comfortable conditions for recreation are young semi-open stands, which are characterized by the most optimal temperature conditions inside the forest park (compared to the open space), humidity and wind retention coefficient.

Conclusions. The study of the peculiarities of forestry management in suburban forests, ecological features of forest areas of the city, their characteristics was conducted. It should be noted that suburban forests play an extremely important role in the urban environment. First of all, they regulate the microclimate in the city, besides, forest zone is a place for recreation. Currently, the main problem of suburban forests is their non-rational management, especially in the field of recreation. Accordingly, relevant findings were made and recommendations for cultivation of stable forest plantations were suggested:

- the system of fellings should be changed and improved;

- timely sanitary fellings aimed at removal of sick and infected stands should be carried out;

- system for suburban forests recreational zones creation should be improved and strict sanitary control over these territories should be introduced;

- recreational loads regulation shoud be implemented in order to avoid excess of the maximum allowable one, at which forest ecosystems are capable of selfrestoration;

- in the areas of mass recreation loads should be reduced by improving the walkways networks, creation and furnishing the sites for various recreational purposes, timely implementation of measures for the protection and preservation of forests shoud be provided;

- areas that belong to the 4th and 5th stages of recreational digression should be temporarily (for 3-5 years) exclude from the scope of use together with the simulteneous carriage of care measures, increasing growth and stability of plantations.

\section{Список використаної літератури}

1. Кирилюк С., Попков М. Про поділ лісів на групи та категорії захисності. Лісовий та мисливський журнал. 2000. № 6. С. 12-13

2. Курило О. В. До проблеми впровадження рубок формування ландшафтів у лісопаркових частинах зелених зон міст. Науковий вісник Національного аграрного університету. К.: НАУ, 2003. Вип. 61. С. 47-54.

3. Родічкін І. Д. Лісопарки України. К.: Будівельник, 1968. 168 с.

4. Свириденко В.С. Рекреаційне лісівництво. К.: НАУ, 2003. 110 с.

5. Тюльпанов Н. М. Лесопарковое хозяйство. Изд. 2-е, перераб. М.: Стройиздат, $1975.160 \mathrm{c.}$

6. Кучерявий В.П. Озеленення населених місць. Львів: Світ, 2005. 456 с.

7.Рубцов Л.И. Проектирование садов и парков. М: Изд-во лит. по строительству, 1964. 234 с. 
8. Нормативно-справочные материалы для таксации лесов Украины и Молдавии. Киев: Урожай, 1987. 560 с.

9. Площі пробні лісовпорядні. Метод закладання: [СОУ 02.02-37-476: 2006. Чинний від 2007-05-01]. К.: Мінагрополітики України, 2006. 32 с. (Стандарт організації України)

\section{Список літератури у транслітерації / References}

1. Kyryliuk S., Popkov M. (2000). Pro podil lisiv na hrupy ta katehorii zakhysnosti. [On the division of forests into groups and categories of protection]. Lisovyi ta myslyvskyi zhurnal - Forest and hunting magazine. № 6. 12-13 [in Ukrainian].

2. Kurylo O. V. (2003). Do problemy vprovadzhennia rubok formuvannia landshaftiv u lisoparkovykh chastynakh zelenykh zon mist [To the problem of introduction of fellings of formation of landscapes in forest park parts of green zones of cities]. Naukovyi visnyk Natsionalnoho ahrarnoho universytetu - Scientific Bulletin of the National Agrarian University. K.: NAU. Issue. 61. 47-54 [in Ukrainian].

3. Rodichkin I. D. (1968). Lisoparky Ukrainy [Forest parks of Ukraine]. K.: Budivelnyk. [in Ukrainian].

4. Svyrydenko V. Ye. (2003). Rekreatsiine lisivnytstvo [Recreational forestry]. K.: NAU. [in Ukrainian].

5. Tiulpanov N. M. (1975). Lesoparkovoe khoziaistvo [Forestry]. Yzd. 2-e, pererab. M.: Stroiyzdat. [in Russian].

6. Kucheryaviy V.P. (2005). Ozelenennya naselenih mists [Greening of settlements]. Lviv: Svit. [in Ukrainian].

7. Rubtsov L.I. (1964). Proektirovanie sadov i parkov [Designing gardens and parks]. M.: Izd-vo lit. po stroitelstvu. [in Russian].

8. Normatyvno-spravochnue materyalu dlia taksatsyy lesov Ukraynu y Moldavyy. (1987). [Normative reference materials for taxation of forests of Ukraine and Moldova] Kyev: Urozhai. [in Russian].

9. Ploshchi probni lisovporiadni. (2006). Metod zakladannia [Square trial forest management. Method of laying]: SOU 02.02-37-476: 2006. Chynnyi vid 2007-0501]. K.: Minahropolityky Ukrainy - Ministry of Agrarian Policy of Ukraine. (Standart orhanizatsii Ukrainy) [in Ukrainian].

\section{АННОТАЦИЯ}

\section{ОСОБЕННОСТИ ФОРМИРОВАНИЯ УСТОЙЧИВЫ К РЕКРЕАЦИОННОЙ НАГРУЗКИ ЛЕСОПАРКОВОЙ НАСАЖДЕНИЙ Г. ВИННИЦЫ}

Проведенные нами исследования заключались в оиенке особенностей внутривидовой и межвидового взаимодействия господствующих древесных пород в лесопарковых насаждениях зеленой зоны г. Виннищы, а также определение приоритетных таксаиионных их показателей формирования древостоев с высокой конкурентной способностью. 
В результате исследований было установлено, что основными показателями, которые непосредственно влияют на конкурентные свойства элементов леса, является санитарное состояние лесных насаждений; состав древостоя и его ярусность; наличие подроста и подлеска; биологические и экологические особенности отдельных древесных пород; полнота древостоя; возраст насаждения; тип лесорастительных условий; особенности микроклимата и микрорельефа. Из анализа санитарного состояния пробных площуадей следует, что степень конкурентной способности лесных насаждений с высоким количеством засохиих или поврежденных деревьев значительно ниже, чем в насаждениях с лучиим санитарным состоянием.

Табл. 2. Рис. 2. Лит.9.

\section{АНОТАЦІЯ \\ ОСОБЛИВОСТІ ФОРМУВАННЯ СТІЙКИХ ДО РЕКРЕАЦІЙНОГО НАВАНТАЖЕННЯ ЛІСОПАРКОВИХ НАСАДЖЕНЬ М. ВІННИЦІ}

Проведені нами дослідження полягали в оичіниі особливостей внутрішньовидової та міжвидової взаємодї пануючих деревних порід $у$ лісопаркових насадженнях зеленої зони м. Вінниці, а також визначення пріоритетних таксаційни х показників формування лісостанів із високою конкурентною здатністю.

В результаті досліджень було встановлено, щуо основними показниками, які безпосередньо впливають на конкурентні властивості елементів лісу, $\epsilon$ санітарний стан лісових насаджень; склад деревостану та його ярусність; наявність підросту та підліску; біологічні та екологічні особливості окремих деревних порід; повнота деревостану; вік насадження; тип лісорослинних умов; особливості мікроклімату та мікрорельєфу. 3 аналізу санітарного стану пробних площ випливає, щуо ступінь конкурентної здатності лісових насаджень із високою кількістю усохлих або пошкоджених дерев значно нижчий, ніж $у$ насадженнях із кращим санітарним станом. Нами досліджено також залежність особливостей конкурентної здатності та напруженості росту деревостану від його повноти та від типу лісопаркового ландшафту. Так деревостани закритих типів характеризуються високим ступенем конкурентної здатності. У напіввідкритих типах лісопаркових ландиафтів показник напруженості росту найвищий величин. Конкурентна здатність дерев у такому типі ландшафту доволі низька. Аналізуючи температурний режим в різних за складом лісопарках було встановлено, щзо в спекотну погоду температура навколичнього середовища в лісопарку набагато нижча, ніж температура повітря на відкритому місиі. Тому в жарку дискомфортну погоду оптимальним типом лісових насаджень для відпочинку є закритий тип ландшафту вертикальної зімкнутості. Температура повітря тут порівняно з відкритим місцем може бути суттєво нижчою (до $\left.15^{\circ} \mathrm{C}\right)$, щзо створює умови для відпочинку із комфортним температурним режимом. 
Аналізуючи вологість повітря лісопарків, встановлено, щцо під пологом лісових насаджень вологість повітря вища порівняно із відкритим місцем, тому рекомендації щодо вибору типу лісового ландмафту для рекреаиіі залежать від початкової вологості.

Ключові слова: рекреація, лісопарки, внутрішньовидова взаємодія, лісопарковий ландшафт, зимостійкість, температурний режим, інтенсивність освітлення, вологість повітря.

Табл. 2. Рис. 2. Літ. 9.

\section{Інформація про автора}

Матусяк Михайло Васильович - кандидат сільськогосподарських наук, доцент, старший викладач кафедри лісового, садово-паркового господарства, садівництва та виноградарства Вінницького національного аграрного університету (21008, м. Вінниця, вул. Сонячна 3. e-mail: mikhailo1988@gmail.com).

Матусяк Михаил Васильевич - кандидат сельскохозяйственных наук, доцент, старший преподаватель кафедры лесного, садово-паркового хозяйства, садоводства и виноградарства Винницкого национального аграрного университета (21008, г. Винница, ул. Солнечная, 3. e-mail: mikhailo1988@gmail.com).

Matusiak Mikhailo - PhD of Agricultural Sciences, Associate Professor, Senior lecturer of the Department of Forestry, Landscape Gardening, Horticulture and Viticulture of Vinnytsia National Agrarian University (21008, Vinnytsya, Sonyachna st. 3, e-mail: mikhailo1988@gmail.com). 